\title{
Penganusutamaan Nilai-nilai Sufisme dalam Pendidikan Islam Indonesia Kontemporer
}

\author{
Rubaidia) \\ a) Universitas Islam Negeri Sunan Ampel Surabaya
}

\section{ABSTRAK}

Artikel ini menelaah dan mendiskusikan kembali arti penting dimensi nilai-nilai sufisme sebagai ruh dasar bagi pendidikan Islam Indonesia dewasa ini di tengah berbagai problematika sosialnya. Tulisan yang didasarkan atas riset partisipatoris pada psudosufi, yakni Majelis Shalawat Adlimiyah di Bojonegoro dan Pasuruan. Temuan menunjukkan efektifitas dimensi sufisme dalam mereduksi dekadensi moral di satu sisi dan menguatkan pendidikan karakter di sisi lain. Relasi guru-murid sebagai inti ajaran sufisme menjadi titik masuk sekaligus modal bagi proses-proses pembentukan kepribadian dan akhlaq yang keduanya merupakan essensi dari pendidikan karakter. Praktik demikian ini telah terjadi selama ratusan tahun dalam tradisi pendidikan sufisme dan masih berjalan hingga saat ini. Salah satu representasinya melalui pendidikan sufisme dalam Majelis Shalawat Adlimiyah. Tulisan ini menyarankan bahwa kebutuhan melakukan pengarusutamaan nilai-nilai sufisme ke dalam pendidikan Islam menjadi kebutuhan mendesak dalam menjawab problematika pendidikan Islam Indonesia kontemporer.

\section{ABSTRACT}

This article reexamines and rediscusses the importance of the dimensions of Sufism virtues as the foundational spirit of Indonesian Islamic education today amidst its social dynamics. This article is based on participatory research on psudo-Sufism, namely the Shalawat Adlimiyah located in districts of Bojonegoro and Pasuruan. Findings show that the Sufism dimension is effective in reducing moral decadence and strengthening character education. The teacher-student relationship as the core of Sufism teachings is the entry point as well as a capital for the processes of shaping personality and morality, both of which are the essential in character education. This practice has occurred for hundreds of years in the tradition of Sufism education and is still ongoing today. One of its representations is through Sufism education in the circles of Shalawat Adlimiyah. This paper suggests that mainstreaming Sufism values into the practice of Islamic education is urgently needed in addressing the problems of contemporary Indonesian Islamic education.
KATA KUNCI

Sufisme; Majelis Shalawat Adlimiyah; Relasi Guru-murid; Pendidikan Karakter.

\section{KEYWORDS}

Sufism; Majelis Shalawat Adlimiyah; Teacher-student Relation; Character Education.

\section{A. Pendahuluan}

Dunia pendidikan Islam di Indonesia kontemporer dihadapkan pada problematika yang kompleks. Kompleksitas problematika pendidikan Islam di Indonesia semakin besar tantangannya memasuki suatu fase atau era yang disebut sebagai era distruptive dan era post-truth. Era disrupsi mengacu kepada era yang ditandai dengan perkembangan teknologi informasi dan komunikasi yang 
menciptakan perubahan fundamental terhadap kehidupan sosial manusia. ${ }^{1}$ Sementara, era post-truth adalah suatu era yang ditandai dengan sirkulasi informasi tanpa batas yang diproduksi oleh mediamedia alternative (media sosial) tanpa lagi mengindahkan prinsip-prinsip kebenaran ilmiah. ${ }^{2}$ Era posttruth ditandai dengan fenomena berita hoax, fake news, dan hate speech. ${ }^{3}$

Sebagai ekses dan implikasi nyata bagi dunia pendidikan Islam di Indonesia setidaknya menghadapi 2 (dua) problem mendasar; (1) Merebaknya dekadensi moral di kalangan siswa secara berjenjang; mulai sekolah dasar, ${ }^{4}$ menengah-atas, ${ }^{5}$ bahkan hingga mahasiswa; ${ }^{6}(2)$ Menguatnya faham radikalisme atau fundamentalisme Islam di kalangan pelajar di berbagai institusi pendidikan menengah-atas hingga pendidikan tinggi di berbagai daerah di Indonesia. Banyak data riset yang meneliti fenomena fundamentalisme di kalangan pelajar. Salah satu riset dilakukan oleh Ma'aarif institute, 2011, dengan mengambil sampel 50 sekolah yang terbagi di 3 (tiga) daerah (Pandeglang, Cianjur, Yogyakarta, dan Solo). Hasilnya secara jelas mengafirmasi terhadap kuatnya faham radikal di kalangan pelajar ini. ${ }^{7}$ Seperti halnya riset Ma'arif Institute, Wahid Institute dalam Isurvey 2016 terhadap Organisasi Rohani Islam (Rohis) Sekolah Menengah Atas Negeri di Indonesia menunjukkan, bahwa, $60 \%$ responden bersedia menjalankan jihad dan $41 \%$ menginginkan Islam harus digabung dalam satu kekhilafahan. ${ }^{8}$

Di tengah krisis multidimensional ini, pemerintah mulai menggaungkan arti penting tentang pendidikan karakter dalam sistem pendidikan nasional. Menurut Kemendiknas, pendidikan karakter dimaknai sebagai upaya menanaman kecerdasan dalam berfikir, penghayatan dalam bentuk sikap dan pengamalan dalam perilaku yang sesuai dengan nilai-nilai luhur yang menjadi jati dirinya, diwujudkan dalam interaksi dengan Tuhannya, diri sendiri, antar sesama, dan lingkungannya. ${ }^{9}$ Pendidikan karakter dengan pengertian sederhana dapat dimaknai sebagai pendidikan budi pekerti, pendidikan moral, pendidikan nilai, pendidikan watak, yang bertujuan untuk mengembangkan kemampuan peserta didik

${ }^{1}$ Tian Wahyudi, "Strategi Pendidikan Akhlaq bagi Generasi Muda di Era Disrupsi," TA'LIM: Jurnal Studi Pendidikan Islam, Volume 3, No. 2 (Juli 2020): 15.

2 Abdur Rahman dan Alvin Dwi Rahmawan, "Memperkuat Modal Sosial di Kalangan Umat Islam di Era Post-Truth," Supremasi: Jurnal Pemikiran dan IImu-ilmu Sosial, Hukum dan Pengajaranya, Volume XIV, No. 2 (Oktober 2019 ): 172.

${ }^{3}$ Wahyudi Akmaliah, "Kebenaran yang Terbelah: Populisme Islam dan Disinformasi Politik Elektoral," Ma'arif, Volume 14, No. 1 (Juni 2019): 139. Lihat: Ulya, "Post Truth, Hoax, dan Religiusitas di Media Sosial," Fikrah: Jurnal Ilmu Aqidah dan Studi Keagamaan, Vol. 6, No. 2 (2018): 283-299.

4 Edo Dwi Cahyo, "Pendidikan Karakter Guna Menanggulangi Dekadensi Moral yang Terjadi pada Siswa Sekolah Dasar," Eduhumaniora: Jurnal Pendidikan Dasar, Vol. 9, No. 1 (Januari 2017): 16.

${ }^{5}$ Mochammad Iskarin, "Dekadensi Moral di Kalangan Pelajar: Revitalisasi Strategi PAI dalam Menumbuhkan Moralitas Generasi Bangsa," Edukasi Islamika, Vol. 1, No. 1 (2016): 1-15.

${ }^{6}$ Burhan Nudin, "Konsep Pendidikan pada Remaja," LIERASI, Vol. XI, No. 1 (2020): 63-73.

${ }^{7}$ Ahmad Fuad Fanani, "Fenomena Radikalisme di Kalangan Anak Muda," Ma'arif, Vol. 8, No. 1 (Juli 2013): 4-13.

8 Muhammad Nurul Huda, Intoleransi Kaum Muda di Tengah Kebangkitan Kelas Menengah Muslim Perkotaan (Jakarta: Wahid Institute, 2017), 1-17.

${ }^{9}$ Tim Penyusun, Grand Design Pendidikan Karakter Bangsa (Jakarta: Kementerian Pendidikan Nasional, 2011 ), 9. 
dalam menentukan baik dan buruk, dan mengaplikasikan kebaikan tersebut dalam kehidupan seharihari. $^{10}$

Pembahasan mengenai pendidikan karakter mau tidak mau menjadi diskursus di kalangan para sarjana muslim maupun di lingkungan pendidikan Islam. Padahal, menurut Faturohman, sesungguhnya pendidikan karakter di Indonesia tercermin dalam Pendidikan Agama Islam (PAI). ${ }^{11}$ Argumentasi Faturohman didasarkan atas Peraturan Pemerintah (PP) Nomor 55, tahun 2007, tentang Pendidikan Agama Islam dan Keagamaan Bab I, Ayat 1 yang menjelaskan pendidikan agama adalah pendidikan yang memberikan pengetahuan dan membentuk karakter. ${ }^{12}$ Jika memang demikian adanya, muncul beberapa pertanyaan mendasar; Pendidikan karakter seperti apa dan bagaimana dalam pandangan Pendidikan Agama Islam? Kalau demikian adanya, kenapa dalam berbagai institusi pendidikan Islam masih melahirkan dekadensi moral maupun problem radikalisme Islam?

Untuk menjawab berbagai pertanyaan di atas, artikel ini akan focus pada kajian yang dikembalikan kepada salah satu disiplin dalam ilmu-ilmu keislaman, yakni tasawuf atau sufisme. Sebagai cabang tertua, sufisme atau tasawuf sering disamakan dengan akhlaq-tasawuf, tauhid, maupun tasawuf itu sendiri. Argumentasi dasar, tasawuf atau sufisme terbukti berhasil membentuk karakter peserta didik (santri) selama berabad-abad dalam institusi pendidikan Islam, terutama pesantren, tarekat, maupun ordo-ordo sufi lain dalam bentuk majelis dzikir, majelis shalawat, dan sebagainya. Warisan ajaran maupun nilai-nilai tasawuf sampai hari ini terbukti masih efektif dalam membentuk ahklaq santri di berbagai institusi pendidikan Islam tersebut. Sayang, dalam konteks modern ini, tasawuf atau sufisme tidak banyak dikaji secara massif oleh peserta didik. Dalam tradisi pesantren pun, tasawuf sering kali ditempatkan sebagai "ilmu tua" yang hanya dikaji oleh santri dewasa. ${ }^{13}$ Ironinya lagi, di kalangan modernis, tasawuf atau sufisme bahkan diharamkan karena dianggap sebagai biang dari kemunduran umat Islam.

Untuk menganalisis peran nilai-nilai sufisme dalam konteks pendidikan Islam di Indonesia, artikel ini akan merekonstruksi konsep maupun praktik ajaran dan nilai sufisme dalam institusi sufisme pada Majelis Shalawat. Majelis Shalawat dimaksud adalah Majelis Shalawat Adlimiyah di bawah Mursyid Gus Mursyidin, ${ }^{14}$ berbasis di Bojonegoro dan Pandaan, Pasuruan, yang tidak lain merupakan institusi pendidikan Islam non formal yang menjadi bagian dari psudo-sufi yang akhir-akhirnya banyak

\footnotetext{
${ }^{10}$ Edo Dwi Cahyo, Pendidikan Karakter Guna Menanggulangi Dekadensi Moral, 18.

${ }^{11}$ Oman Faturohhman, "Kontribusi Pendidikan Karakter dalam Sistem Pendidikan Nasional," Eduprof, Volume. 1, No. 1 (Pebruari 2019): 1.

12 Peraturan Pemerintah Nomor. 55, tahun 2007, tentang Pendidikan Agama Islam dan Keagamaan, terutama Bab I, Ayat 1.

${ }^{13}$ Fenomena ini terlihat dalam tradisi pesantren dalam hal mempelajari kitab Ihya ulumuddin karya al-Ghazali. Di kalangan pesantren, para santri yang belum dewasa dilarang mengikuti pengajian kitab lhya ini karena dianggap memiliki bobot kajian yang berat dan dapat membahayakan mental dan psikologi para santri.

14 Nama di atas adalah nama inisial atau samaran atas permintaan yang bersangkutan karena tidak ingin dipublikasikan by name dalam tulisan ini.
} 
berkembang di Indonesia, selain institusi tarekat. Di sebut sebagai institusi pendidikan Islam non formal, karena Majelis Shalawat ini dibimbing seorang mursyid juga memiliki ribuan murid atau santri. Metode keteladanan merupakan salah satu metode pembelajaran yang ditransmisikan dari mursyid (guru) kepada murid dan secara efektif berhasil membentuk pendidikan karakter.

Justifikasi terhadap studi pada majelis shalawat ini terletak pada sistem pendidikan dan relasi guru-murid dalam proses pembentukan karakter kepribadian (akhlaq). Relasi guru-murid menjadi crusial point, relasi ini menjadi entry point sekaligus pra syarat mutlak bagi pembentukan karakter murid.Meskipun sistem pendidikan yang diperagakan oleh mursyid tidak day to day atau live in di pesantren, namun, berhasil membentuk banyak murid yang memiliki kepribadian atau karakter sesuai dengan prinsip-prinsip pendidikan Islam, lebih-lebih perspektif sufisme, yakni insan kamil.Sistem pendidikan ini dipraktikkan sendiri oleh Gus Mursyidin takala masih berguru kepada guru-gurunya juga terhadap para muridnya. Sebaliknya, di banyak lembaga pendidikan Islam yang face to face maupun live in dengan guru/kyai belum tentu dapat membentuk murid dengan karakter atau kepribadian yang unggul.

\section{B. Guru dalam Epistimologi dan Praktik Sufisme}

Guru dalam terminologi sufisme lebih dikenal dengan mursyid atau murabbi. Dalam satu kesatuan epistimologi sufisme, guru menempati posisi sentral. Disebut sentral karena berporos pada eksistensi guru terbentuk epistimologi keilmuan sufi. Walaupun epistimologi sufisme antara satu guru dengan guru lainnya pada prinsipnya sama, yakni berisi doktrin yang bermuara kepada tauhid keesaan Tuhan (Allah). Namun dalam praktiknya, antara satu guru dengan lainnya memiliki atau membangun sistem epistimologi yang independen. Sebagai contoh adalah Ibnu al-'Arabi membangun epistimologi sufisme dengan konsep wihdat al-Wujud. ${ }^{15}$ Berbeda al-'Arabi berbeda pula dengan Abu Yazid alBustomi terkenal dengan konsep ittihad. ${ }^{16}$ Begitu juga, Hallaj al-Mansur memiliki konsep hulul, ${ }^{17}$ al-Jilli merumuskan konsep tajalli, ${ }^{18}$ dan seterusnya. Selain disebut di atas, para tokoh sufi besar seperti alJaelani, al-Syadzili, al-Ghazali dan lainnya, membangun epistimologi berbeda dalam konteks menjelaskan hubungan antara manusia dengan Tuhan.

Epistimologi yang dibangun dengan basis ajaran tauhid oleh setiap guru menjadi guiden bagi para pengikutnya. Proses transmisi ajaran maupun doktrin dari guru kepada murid dari masa ke masa lambat laun terlembagakan. Proses pelembagaan ini dalam tradisi pendidikan sufisme dikenal dengan

\footnotetext{
15 Ali Akbar, "Looking at Ibn 'Arabi's Notion of Wihdat al-Wujud as Basis for Plural Path to God," Journal of Islamic Studies and Culture, Vol. 4, No. 1 (June 2016): 45-51. Lihat juga: Media Zainul Bahri, "Ibn "Arabi and the Transendental Unity of Religions," Al-Jamiah, Vol 50, No. 2 (2012): 461-481.

16 Oom Mukarramah, "Ittihad, Hulul, dan Wahdat al-Wujud," Jurnal Tazkiya, Vol 16, No. 1 (Januari-Juni 2015): 129141.

17 Micheal Feener, A Re-Examanation of the Place of al-Hallaj in the Development of Southeast Asian Islam (Leiden: KITLV, 1998), 571-588.

${ }^{18}$ Abdul Karim al-Jilli, Al-Insan al-Kamil fi Ma'rifat al-Awakhiri wa al-Awaili (Beirut: Dar al-Kitab al-Ilmiah, 2010).
} 
istilah tarekat. Karena itu, tarekat sesungguhnya dapat dimaknai sebagai jalan menuju Tuhan yang berisi epistimologi keilmuan yang terdiri dari doktrin maupun ajaran yang disusun oleh gurunya. ${ }^{19}$ Bagi para penganut al-'Arabi dengan epistimologi wihdat al-Wujud akan mengikuti jalan (baca: tarekat) yang telah dirumuskannya. Pengikut al-'Arabi dengan sendirinya akan membentuk intellectual chains dari masa ke masa. Tidak mengherankan apabila ajaran wihdat al-Wujud ini menyebar ke Indonesia dengan para pengikutnya yang direpresentasi mulai dari Siti Jenar, Hamzah Fansuri, al-Mutamakkin, dan seterusnya. Al-Jaelani, system ajarannya terlembagakan dalam tarekat yang diberi nama sesuai pendirinya, yakni Tarekat Qadiriyah. Para pengikut al-Syadzili melembagakan ajaran gurunya menjadi suatu tarekat yang dinisbahkan kepadanya dengan nama Tarekat Sadziliyah. Begitu seterusnya.

Inilah dasar yang menempatkan dimensi sufisme berbeda dengan dimensi keilmuan lainnya. Guru sebagai pusat keilmuan begitu sentralnya. Pada prinsipnya, sistem pendidikan Islam secara keseluruhan mengadopsi ajaran dalam sufisme dengan berbagai derivasinya. Karena itu, para guru ini merumuskan konsepsi tentang sistem pendidikan Islam berbasis nilai-nilai sufisme. Di antara karya klasik yang masih up to date dan selalu menjadi rujukan hingga saat ini adalah karya al-Jarnuji dalam kitabnya berjudul ta'lim al-Muta'allim. ${ }^{20}$ Kitab ini sifatnya umum dan hingga saat ini masih menjadi kurikulum wajib di pesantren seluruh Indonesia. Di atas kitab karya al-Jarnuji, terdapat karya al-Ghazali yang berjudul ayyuha al-Walad. ${ }^{21}$ Dibanding dengan ta'lim al-Muta'allim, bobot kitab ayyuha al-Walad lebih tinggi. Karena itu, karya al-Ghazali lebih khusus menjadi guiden bagi para murid yang mengikuti pendidikan di bawah bimbingan para guru sufi.

Baik karya al-Jarnuji maupun al-Ghazali mengulas dan menempatkandua tema sentral; (1) Makna guru, dan (2) Relasi guru-murid. Namun demikian, antara teori dan praktik terdapat jurang (gap) yang cukup menganga. Kerangka teori, baik di rumuskan al-Ghazali, al-Jarnuzi, maupun banyak guru-guru sufi lain menjadi teks yang sifatnya normatif. Artinya, teks dimaksud sepertinya berhenti hanya pada ranah konsep, teori, bahkan menjadi korpus tertutup. Selain bersifat ideal-teoritis, tidak banyak yang menjelaskan atas basis pengalaman impiris. Al-Ghazali dalam ayyuha al-Walad memberi batasan ideal-normatif tentang hakekat guru dalam tradisi sufi. Lebih jauh, al-Ghazali mengatakan:

"Syarat seorang syekh (baca: guru) yang mengganti Rasulullah adalah seorang yang alim. Tetapi, tidak setiap orang yang alim adalah guru. Adapun sebagian tanda-tanda seorang alim dimaksud adalah tidak tertarik terhadap dunia dan ketenaran. Sebaliknya, ia adalah

${ }^{19}$ A.R.Iga Megananda Pratama, "Urgensi dan Signifikansi Mursyid bagi Murid dalam Tarekat," Jurnal Yaqzhan, Volume 4, Nomor 1 (Juni 2018): 54-55.

${ }^{20}$ Burhan al-Islam al-Jarnuzi, Ta'lim al-Muta'allim Tariq al-Ta'lim, (Dar Ihya' al-Kutub al-'Arabiyah, t.th).

${ }^{21}$ Kitab "Ayyuha al-Walad" karya al-Ghazali, meskipun judulnya seperti untuk anak-anak, tetapi sebagai panduan (code of conduct) bagi para salik yang mengikuti jalan spiritual guru-guru tasawuf. Lihat: Imam al-Ghazali, Ayyuha alWalad, al-Haramain Jaya Indonesia, tt. 
yang baik, banyak riyadlah, sedikit makan, bicara, tidur, dan memperbanyak shalawat, shadaqah, dan puasa." 22

Guru dalam perspektif sufisme, menurut al-Ghazali, berperan sebagai guiden yang membimbing murid ke jalan yang lurus. Begitu sentralnya, al-Ghazali sampai membuat diktum terkenal; "seseorang yang tidak memiliki mursyid (guru), syetan adalah gurunya." ${ }^{23}$ Karena itulah, guru dinarasikan dengan simbol sebagai asrafu al-Nas fi-al-Thariqah (orang yang paling tinggi derajatnya dalam tarekat). ${ }^{24}$ Sebagai identitas sekaligus syarat seorang guru dalam semua pendapat guru sufi, bahwa guru adalah seorang 'arif atau ma'rifat. Makna 'arif atau ma'rifat dalam pandangan al-Jilli disederhanakan dengan konsep al-Insan al-Kamil. Pada tingkat tertentu, makna 'arif atau ma'rifat menurut al-Jilli tentu berbeda dengan yang lainnya.

Antara al-Ghazali, al-'Arabi, maupun al-Jilli secara essensi mendefinisikan sosok guru dengan pengertian yang sama, namun berbeda dalam penekanannya. Inti dari epistimologi guru atau mursyid lebih menekankan kepada sosok dalam derajat (maqamat) telah mencapai maqam makrifat. Dalam karya adab al-Alim wa al-Muta'allim, KH. Hasyim Asy'ari juga mendefinisikan sosok guru atau mursyid didasarkan atas dalil-dalil, baik al-Qur'an maupun hadist. ${ }^{25}$ Singkatnya, sosok guru, dalam konsep KH. Hasyim Asy'ary, digambarkan sebagai ulama yang takut kepada Allah, tinggi ilmunya, mengamalkan seluruh ilmunya, memiliki derajat yang begitu tinggi secara horizontal dan vertikal, serta memiliki akhlak al-Karimah. Ciri-ciri guru yang demikian ini, dalam garis besarnya adalah para ulama yang telah mencapai derajat makrifat. ${ }^{26}$

Sayangnya, konsep-konsep di atas sifatnya normatif dan berhenti pada level teori atau diskursus saja. Konsep ini cenderung berhenti hanya sebagai corpus tertutup. Tidak banyak yang mampu mengelaborasi dalam wujud pengalaman empiris dalam relasi guru-murid. Bagaimana praktik dalam wujud konkrit. Dalam tradisi pendidikan sufi ini, seorang guru diilustrasikan sebagai sosok yang kamil dan mukammal (sempurna dan menyempurnakan) terhadap seorang murid. la memiliki kemampuan dan keilmuan yang holistik. Dimensi ini sulit dinarasikan alias, beyond imagination. Hanya para salik ${ }^{27}$ yang mampu merasakan dan meresapi hakekat eksistensi seorang guru ini.

Konsep yang sifatnya abstrak di atas, sesungguhnya masih dapat dijelaskan secara lebih operasional dan teknis. Gus Mursyidin, mursyid Majelis Shalawat Adlimiyah, suatu institusi psudo-sudi,

22 Imam al-Ghazali, Ayyuha al-Walad (Indonesia: al-Haramain Jaya, tt.), 14.

${ }^{23}$ Imam al-Ghazali, Ihya Ulum al-Din, Bab al-Halabi (Cairo: tanpa penerbit, 1343 H), 42.

${ }^{24}$ Cece Alba, Cahaya Tasawuf (Bandung: CV. Wahana Karya Grafika, 2009), 145.

${ }^{25}$ Sebagai ulama ahli hadist, dalam karyanya, KH. Hasyim Asy'ari, selain mengutip ayat-ayat al-Qur'an, beliau banyak mengutip hadist yang terkait dengan penggambaran sosok guru ini. Lihat: KH. Hasyim Asy'ary, Adab al-Alim wa alMuta'allim, Editor, KH. Ishomuddin Hadziq, PP. Tebu Ireng, tanpa tahun, hal. 1-102.

${ }^{26} \mathrm{KH}$. Hasyim Asy'ary, Adab al-Alim wa al-Muta'allim, Editor, KH. Ishomuddin Hadziq (Jombang: PP. Tebu Ireng, tanpa tahun), 1-21.

27 Istilah salik dapat dimaknai sebagai seseorang yang menempuh jalan tasawuf dalam bimbingan seorang guru tasawuf. Predikat salik dalam makna lain sama dengan murid. Tetapi, istilah salik hanya berlaku dalam tradisi tasawuf saja dan tidak untuk system pendidikan Islam lainnya. 
secara operasionalmenjabarkan hakekat guru dalam praktik sufisme di atas. Menurutnya, hakekat guru sesungguhnya dapat didekati dengan pendekatan tauhid. Dasar tauhid ini disandarkan pada QS: al-'Alaq: $5^{28}$ dan SQ: al-Baqarah: $255 .{ }^{29}$ Kedua ayat ini, menurut Gus Mursyidin merujuk kepada makna guru sebagai seorang makrifat. Makna makrifat menurutnya adalah seseorang yang telah diajari sendiri oleh Allah sehingga mengetahui segala sesuatu yang tersembunyi. Lebih lanjut, menurut Gus Mursyidin, secara metafora, sosok guru dideskripsikan sebagai berikut:

"Inti dari guru, guru itu ya Pengeran ku. Guru itu ya Nabi ku. Guru itu siapa? ya Qur'an ku. Guru itu siapa? ya Kitab ku. Yang kamu abdikan kepada Allah itu ya wujudnya dari (perintah) guru. Jadi, kalau kita mengabdi kepada guru, berarti mengabdi kepada Allah. Siapa guru itu, ya jelmaan (baca: perwujudan) pengeran," Tandas Gus Mursyidin. ${ }^{30}$

Dalam terminologi sufisme, eksistensi dan hakekat seorang guru tidak lain adalah seseorang yang telah mencapai derajat "ketuhanan." Makna derajat "ketuhanan" di sini dimaksudkan, bahwa, seorang guru telah memiliki sifat-sifat ketuhanan dalam dirinya. Sifat-sifat demikian ini bisa ada dalam diri seseorang setelah dibimbing oleh gurunya hingga mencapai proses wusul kepada Rasulullah dan Allah sendiri. Setelah seorang murid mencapai wusul, dengan sendirinya, seorang murid akan menggantikan posisi gurunya. Pada saat seorang murid telah menjadi guru, akan terjadi siklus dimana dirinya akan menempati maqam (kedudukan) gurunya.

Dalam banyak pemikirannya, Gus Mursyidin berusaha membumikan diskursus mengenai konsep guru secara lebih operasional dan praktis. Pemikiran ini didasarkan atas praktik bertahuntahun mengabdi kepada kedua gurunya. ${ }^{31}$ Kedua gurunya diyakini merepresentasikan sosok ideal sebagai para guru seperti kerangka teori yang didiskripsikan oleh para sufi besar di atas. Dengan kata lain, pemikiran-pemikiran yang dikonstruksi oleh Gus Mursyidin lebih didasarkan atas praktik pengabdian kepada kedua gurunya secara langsung. Secara simbolik, lebih jauh Gus Mursyidin mendefinikan hakekat guru;

"Wujudnya Allah itu ya guru. Bahwa, guruku adalah Allah. Tugas murid adalah mentauhidkan. Guru di sini adalah 'allama al-Insana ma lam Ya'lam dan Ya'lamu ma baina aidhihim wa ma khalfahum," 32

Makna guru di atas sepintas bisa menimbulkan pemikiran kontroversial. Tetapi, makna tersebut dalam kerangka konsep wihdat al-Wujud dapat dengan mudah dimengerti. Dalam perspektif wihdat al-Wujud, secara substansi, seseorang yang telah mencapai pucak spiritual, ia akan menyatu

${ }^{28}$ QS: al-'Alaq: 5, berbunyi: “Dia mengajarkan manusia apa yang tidak dia ketahuinya.

${ }^{29}$ QS: al-Baqarah: 255 yang dikenal dengan Ayat Kursi, terutama pada bagian; “(Dia) yang mengetahui apa yang ada di hadapan mereka dan apa yang ada di belakang mereka."

${ }^{30}$ Wawancara dengan Gus Mursyidin, mursyid Shalawat Adlimiyah, di Café Kikko, tanggal 16 Juli 2019.

${ }^{31}$ Gus Mursyidin dalam pendidikan sufinya dididik secara langsung oleh 2 (dua) guru sekaligus, yakni Gus Syamsu Dhuha dan Gus Kahar. Guru yang pertama adalah seorang mursyid Shalawat Kubro di Surabaya. Sedangkan guru kedua adalah Gus Kahar seorang mursyid Shalawat Muhammad juga di Surabaya. Guru kedua, dalam transmisi keilmuan adalah murid dari Gus Syamsu Dhuha.

${ }^{32}$ Wawancara dengan Gus Mursyidin, mursyid Shalawat Adlimiyah, di Café Kikko, tanggal 16 Juli 2019. 
dengan Tuhannya. Eksistensi seorang guru dengan maqam spiritual ini membawa konsekuensi logis, bahwa, seorang murid akan meyakininya sebagai guru sejati, yakni, guru yang memiliki tingkat spiritualitas yang telah menyatu dengan sang Khalik. Dalam referensi sufisme nusantara, doktrin ini dapat dijumpai dalam banyak pemikiran para sufi seperti Siti Jenar, Hamzah al-Fansuri, al-Mutamakkin, dan masih banyak lagi. Melalui pendekatan ini, statement Siti Jenar "ana al-Haq" dapat difahami dengan baik. ${ }^{33}$

Konsep maupun statement Gus Mursyidin di atas sebenarnya dapat dirujuk dalam pemikiran al-Jilly dalam karyanya "al-Insan al-Kamil. Dalam karyanya, al-Jilly menekankan, bahwa, seseorang guru yang telah mencapai derajat kesufian yang tinggi akan mengalami apa yang disebutnya sebagai tajalli. Pengertian tajalli dimaksudkan al-Jilly adalah menyatunya Nur Muhammad dalam diri orang tersebut. Nur Muhammad ini tidak lain adalah eksistensi Allah sendiri. Karena itu, masih menurut al-Jilly, Nur Muhammad telah menyatu dalam diri Muhammad, Rasulullah. Al-Jilly menambahkan, bahwa, Nur Muhammad dapat menyatu ke dalam diri seseorang yang dikehendaki Allah. Menurut al-Jilly, seperti ditulis sendiri dalam karyanya, telah mencapai derajat sufi yang memungkinkan dirinya tajalli dengan Nur Muhammad. ${ }^{34}$

Fakta menarik dari konstruksi pemikiran Gus Mursyidin lebih didasarkan atas ketidaktahuannya akan teori maupun konsep dalam sistem pendidikan sufi. Satu-satunya modal yang dimiliki adalah sistem keyakinan secara total terhadap gurunya sebagai sosok guru sejati. Berbeda dengan kebanyakan relasi guru-murid, seorang murid umumnya membaca teori-teori pendidikan Islam di institusi pendidikan Islam seperti pondok pesantren. Selama nyantri, para murid menelaah di bawah bimbingan kyai tentang teori-teori dasar pendidikan Islam. Setelah para santri membaca dan mengkaji beberapa kitab dimaksud dilanjutkan menerapkan dalam kehidupan sehari-hari. Sebaliknya, pengalaman Gus Mursyidin bertahun-tahun mengabdikan dirinya kepada para gurunya tidak diajari teori maupun ditunjukkan kitab-kitab dimaksud. Satunya-satunya metode yang dijalani dalam belajar bersama gurunya adalah menjalankan seluruh perintah gurunya. Dengan kata lain, pola pendidikan ini sepenuhnya didasarkan atas praktik secara langsung. Dalam tradisi Jawa, pola pendidikan sufisme demikian ini disebut sebagai pendidikan laku atau lelaku.

Dalam konteks modern pun, peran guru sesungguhnya juga sangat vital. Guru menempati posisi kunci dalam relasi guru-murid dalam proses pembelajaran. Walaupun fakta di lapangan, peran sedemikian penting sering kali diabaikan oleh para guru. Peran penting guru ini ditegaskan melalui 4 (empat) kompetensi yang harus dimiliki oleh setiap guru, yakni (1) kompetensi kepribadian, (2)

\footnotetext{
${ }^{33}$ Agus Sunyoto, Atlas Wali Songo: Mengungkap Wali Songo sebagai Fakta Sejarah Cet. VI, (Jakarta: Pustaka Iman, 2017).

${ }^{34}$ Abdul Karim ibnu Ibrahim al-Jilli, al-Insan al-Kamil fi Makrifat, 75-76.
} 
kompetensi paedagogik, (3) kompetensi professional, serta (4) kompetensi sosial. ${ }^{35}$ Keempat kompetensi guru sesuai Undang-undang Nomor 14 tahun 2005 di atas, sesungguhnya selaras dengan perspektif sufisme baik menurut al-Ghazali, al-Jilli, maupun Ibnu al-'Arabi seperti diskripsi sebelumnya. Misalnya saja, makna kompetensi kepribadian sesungguhnya dapat diartikan dengan akhlaq yang mulia.

Setting background pendidikan Gus Mursyidin yang disandarkan sepenuhnya berbasis pada praktik melahirkan pemikiran-pemikiran segar dan lebih operasional. Di satu sisi, pemikirannya dapat menjelaskan tentang konsep-konsep abstrak tentang pendidikan Islam yang selama berabad-abad seperti menjadi corpus tertutup seperti disinggung sebelumnya. Di sisi lain, pemikiran Gus Mursyidin maupun para gurunya menjelaskan suatu konsep yang kelihatannya sederhana, tetapi sesungguhnya memiliki cakupan makna dan pengertian yang begitu mendalam. Semua pemikiran ini diketahui setelah dijalankan secara nyata, lalu dicocokkan dengan konsep-konsep abstrak dalam berbagai kitab dimaksud.

Statement Gus Mursyidin tentang hakekat guru tidak lain adalah "wujud Allah ya guru," sesungguhnya diambil dari doktrin salah satu gurunya, yakni Gus Syamsu Dhuha. ${ }^{36}$ Suatu saat Gus Syamsu mengatakan; "Kon kepingin ngerti al-Qur'an? Yo aku iki al-Qur'an. Kon kepingin ngerti Rasulullah atau Allah? Yo aku Rasulullah yo aku Allah iki," (Anda ingin tahu al-Qur'an? Ya saya ini alQur'an. Anda ingin tahu Rasulullah atau Allah? Ya saya ini Rasulullah Ya aku ini Allah), kata Gus Syamsu. ${ }^{37}$ Pernyataan Gus Syamsu ini ditujukan kepada Gus Kahar saat masih menjalankan salik dan riyadlah di bawah bimbingan Gus Syamsu.

Dikisahkan, suatu saat Gus Kahar semasa mengikuti gurunya berusaha mencuri waktu untuk menemui ibunya. Sebelum menjadi santri, gurunya mengatakan, selama 3 (tiga) tahun tidak boleh menemui kedua orang tuanya. Padahal, kedua orang tuanya tinggal tidak jauh dari kediaman gurunya, yakni di Pesapen Tengah, Surabaya. Padahal, keinginan Gus Kahar menemui ibunya hanya ingin memberi jajan pasar (snack), yakni ote-ote. Tanpa diduga, Gus Syamsu mengetahui apa yang dilakukan muridnya. Dengan nada marah, Gus Syamsu mengatakan;

"Jipuk....Jaluk maneh. Wong tuwo mu ora isok gowo awak mu neng pengeran. Aku seng isok gowo neng pengeran. Yo Aku iki Pengeran mu," (Ambil....ambil lagi. Orang tua mu tidak dapat membawa kepada Allah. Saya yang bisa membawa mu kepada Allah. Ya Aku ini Tuhan mu), kenang Gus Kahar. ${ }^{38}$

\footnotetext{
35 Undang-undang Republik Indonesia Nomor 14 tahun 2005 tentang Guru dan Dosen, bab IV, tentang kualifikasi, kompetensi, dan sertifikasi, hal. 5.

${ }^{36}$ Gus Syamsu Dhuha adalah mursyid Shalawat Kubro yang diwarisi dari gurunya, yakni KH. Muhammad Tamyiz (baca: Mbah Tamyiz). Gus Syamsu Dhuha (1956-2003 M) merupakan guru dari Gus Kahar dan Gus Mursyidin.

${ }^{37}$ Wawancara dengan Untung, salah seorang kakak Gus Mursyidin dan murid dari Gus Syamsu Dhuha dan Gus Kahar, di Pandaan, 19 Agustus 2019.

${ }^{38}$ Dikutip dalam bincang santai dengan Gus Kahar di Excelso Cafe, Mall Tunjungan Plaza, Surabaya, tanggal 14 Juni 2015.
} 
Kisah di atas diceritakan sendiri oleh Gus Kahar. "Ya di kursi itu...menjelang akhir hayatnya, Gus Syamsu, mengatakan Aku jaluk sepuro ya. Awak mu wes tak apak-apakno tapi tidak pernah berubah akidah mu. Besok Aku melok awakmu," lanjut Gus Kahar menceritakan saat-saat terakhir pertemuan dengan gurunya sembari menunjuk kursi yang penulis duduki. ${ }^{39}$ Pernyataan-pertanyaan yang kelihatannya tidak lazim bagi kalangan umum tersebut, sebenarnya bentuk peneguhan aqidah atau ajaran tauhid. Seorang guru atau mursyid telah mencapai keutuhan aqidah, yakni menyatunya dirinya dengan sifat-sifat dan $a f^{\prime} a l$ (tindakan atau perilaku) Allah. Untuk membentuk aqidah seorang murid seperti gurunya diperlukan suatu keyakinan yang utuh pula. Karena itu, Gus Syamsu, seperti dikutip dari Gus Kahar dalam mengilustrasikan proses pembentukan aqidah maupun kepribadian seorang murid harus bersusah payah.

"Kayu jati yang telah diukir memiliki nilai seni dan estetika yang tinggi. Sehingga, harganya mahal. Kalau kamu mengerti, saat kayu jati itu diukir, dia pasti pasti menjerit karena kesakitan. Begitu juga dengan seorang murid yang diukir jiwanya oleh guru,"40

Beberapa statement Gus Syamsu yang dikutip Gus Kahar di atas, secara essensi sesungguhnya menjelaskan tentang konsep-konsep ideal tentang eksistensi guru yang abstrak sebelumnya. Gus Kahar sendiri menyadari kesalahannya saat menengok orang tuanya dengan memberi jajan pasar berupa ote-ote. Dalam pandangan Gus Kahar, seorang guru adalah segala-galanya. Lebih lanjut Gus Kahar menjelaskan, bahwa, hakekat orang tua yang sesungguhnya adalah guru. Sedangkan, sosok orang tua yang melahirkan adalah orang tua secara jasad atau biologis. "Guruku seng isok nggowo neng pengeran. Wong tuwoku durung tentu bisa membawa ke Allah," kata Gus Mursyidin menguatkan pandangan gurunya, Gus Kahar. ${ }^{41}$

Sama dengan Gus Kahar, Gus Mursyidin selama berguru, dalam beberapa tahun juga dipisahkan dari orang tua perempuan. Bahkan, dalam beberapa tahun lamanya, orang tuanya memiliki pandangan negatif terhadap dirinya. Presenden negatif ini dalam kaca mata umum dapat dimaklumi. Sebab, dalam perspektif ajaran sufi, eksistensi guru adalah segalanya. Dengan kata lain, guru secara hakiki adalah orang tua sejati. Sedangkan, orang tua itu sendiri tidak lain adalah orang tua secara jasad. "Besok di antara anak-anak mu ya anak mu nomer empat ini yang akan mengangkat derajat keluarga mu yuk," ungkap Gus Kahar kepada Ibu Gus Mursyidin seperti ditirukannya saat bertemu dalam suatu kesempatan.

Peran guru seperti gambaran di atas secara strike umumnya dipraktikkan dalam tradisi pesantren yang menerapkan sistem boarding school maupun live in. Lebih dari itu, peran guru secara lebih strike seperti dalam teori-teori pendidikan Islam klasik (baca: sufisme) implemented dalam tradisi

\footnotetext{
${ }^{39}$ Dikutip dalam bincang santai dengan Gus Kahar di Excelso Cafe, Mall Tunjungan Plaza, Surabaya, tanggal 14 Juni 2015.

${ }^{40}$ Dikutip dalam bincang santai dengan Gus Kahar di Excelso Cafe, Mall Tunjungan Plaza, Surabaya, tanggal 14 Juni 2015.

${ }^{41}$ Wawancara dengan Gus Mursyidin, mursyid Shalawat Adlimiyah, di Bojonegoro, tanggal 25 Agustus 2019.
} 
sufisme, baik yang terlembagakan dalam tarekat maupun psudo-sufi seperti tercermin dalam majelis Gus Mursyidin maupun guru-gurunya. Secara teoritis, peran maupun fungsi guru demikian ini juga telah menjadi diskursus lama dalam teori pendidikan modern. Dalam perspektif pendidikan modern, fungsi guru dalam proses pendidikan mencakup; (1) transfer of knowledge (alih pengetahuan), (2) transfer of methodology (alih metode), dan (3) transfer of values (alih nilai). ${ }^{42}$

\section{Nilai-nilai Pendidikan Sufisme dan Proses Pembentukan Karakter}

Pada akhirnya, Gus Syamsu sebagai guru dari Gus Kahar dan Gus Mursyidin menjelang akhir hayat mengatakan kepada banyak muridnya. "Murid ku ribuan. Sakmono akehe, ora onok seng weruh aku, ora onok seng isok nembus langit sap pitu, kejobo Kahar karo ...... (baca: Gus Mursyidin)," (Murid ku berjumlah ribuan. Tidak yang tahu tentang saya. Tidak ada yang dapat menembus langit ketujuh, kecuali Kahar dan Mursyidin), tegas Gus Syamsu seperti ditirukan Untung. ${ }^{43}$ Ungkapan ini keberhasilan seorang guru dalam mendidik dan "mengkader" para muridnya. Dalam tradisi sufisme, tidak mudah bagi guru (mursyid) melahirkan di antara muridnya sebagai pewaris keilmuan. Tidak seluruh murid dapat menjadi pewaris utama paska gurunya wafat. Para murid dapat saja mewarisi keilmuan guru, tetapi, tidak secara total. Sebaliknya, seorang murid yang menjadi pewaris dicirikan penguasaan secara total, bahkan menyempurnakan dimensi-dimensi keilmuan guru.

Narasi dalam paragraf di atas menjadi justifikasi tentang keberhasilan guru menurut tradisi sufi dalam membentuk karakter murid. Dengan kata lain, sufisme sebagai bagian dari disiplin ilmu-ilmu keislaman memiliki andil yang demikian besar. Bahkan, pendidikan Islam dalam pengertian spesifik adalah pendidikan berbasis nilai dan ajaran sufisme. Dalam historisitas panjang, pendidikan berbasis ajaran sufismeterbukti mampu melahirkan para murid yang berkarakter. Bukti konkrit pendidikan karakter melalui pendidikan sufisme adalah; selain bertahannya institusi sufi (baik tarekat maupun psudo-sufi) selama ratusan tahun juga reproduksi murid yang menggantikan peran para guru (mursyid) sufi. Dengan kata lain, pendidikan sufi telah lama menjadi ideal type pendidikan karakter yang digaungkan oleh dunia pendidikan modern akibat krisis multi dimensional yang dihadapi dunia pendidikan saat ini.

Ciri utama guru dalam tradisi sufisme adalah kepribadian yang utuh. Kepribadian sendiri tidak lain adalah 1 (satu) di antara 4 (empat) kompetensi guru. Kepribadian dimaksud dalam kompetensi guru dapat dimaknai dan diasosiasikan dengan akhlaq. ${ }^{44}$ Akhlaq sendiri dalam keseluruhan konsepsi sufisme menempati urutan tertinggi. Tujuan pendidikan Islam atau Islam sendiri dalam satu kata

\footnotetext{
42 Ali Sunarso, "Revitalisasi Pendidikan Karakter melalui Internalisasi Pendidikan Agama Islam (PAI) dan Budaya Religius," Kreatif: Jurnal Kependidikan Dasar, Volume 10, No. 2 (2020): 158.

${ }^{43}$ Wawancara dengan Untung, salah seorang kakak Gus Mursyidin dan murid dari Gus Syamsu Dhuha dan Gus Kahar, di Pandaan, 19 Agustus 2019.

${ }^{44}$ Ali Sunarso, Revitalisasi Pendidikan Karakter.
} 
adalah akhlaq. Akhlaq dimaksud sebagai referensi adalah akhlaq Rasulullah dan Allah. Seorang guru sufi merepresentasikan akhlaq Rasulullah maupun akhlaq Allah. Di sinilah konsep Gus Mursyidin di atas dapat ditarik benang merahnya. Karena itu, apabila seorang guru berhasil melahirkan murid yang mewarisi keilmuannya, maka, murid tersebut dipastikan memiliki akhlaq seperti gurunya. Inilah sesungguhnya korelasi pendidikan karakter dalam keseluruhan pendidikan bebasis nilai dan ajaran sufisme seperti tergambar dalam paragraf di atas.

Pendidikan karakter dalam pengertian yang banyak dibahas di kalangan para akademisi akhirakhir ini dimaknai sebagai pendidikan budi pekerti, pendidikan moral, pendidikan nilai, pendidikan watak yang bertujuan mengembangkan kemampuan murid dalam kehidupan sehari-hari. ${ }^{45}$ Menurut Kemendiknas, pendidikan karakter adalah pendidikan budi pekerti plus; melibatkan aspek pengetahuan (knowledge), perasaan (feeling), dan tindakan (action). ${ }^{46}$ Dalam konteks kepentingan Indonesia, point utama pendidikan karakter, melalui peran guru terhadap siswa diarahkan dalam membentuk sikap religious, nasionalis, mandiri, gotong royong, dan integritas. ${ }^{47}$ Nilai-nilai pendidikan karakter bersumber dari nilai-nilai agama, pancasila, sosial, dan budaya. Pendidikan karakter perlu proses, keteladanan, pembiasaan dalam lingkungan sekolah, keluarga, dan masyarakat. ${ }^{48}$ Dari konteks ini, sesungguhnya pendidikan karakter dimaksud telah diproduksi dan terus direproduksi dalam tradisi pendidikan sufi.

Berdasarkan banyak data yang ditulis dalam bentuk kutipan-kutipan dialog di atas pada bagian ini masih dapat dianalisis lebih mendasar dan praksis lagi. Analisis ini penting dalam konteks pembacaan terhadap praktek dan realitas pendidikan di Indonesia secara umum dan pendidikan Islam secara khusus. Analisis ini memiliki makna penting dalam kerangka teoritik bagi rekonstruksi praktek dan teori pendidikan Islam di Indonesia. Sebab, kritik terhadap epistimologi pendidikan Islam secara makro hingga dewasa ini belum menemukan bentuknya yang relatif mapan dan disepakati oleh sebagian besar para sarjana muslim. Salah satu problem mendasar adalah mensinergikan antara tujuan pendidikan Islam, kurrikulum, dan keluaran (out put) pendidikan itu sendiri. ${ }^{49}$ Dalam konteks Indonesia, sejak awal, terdapat kerancauan berfikir dalam reformasi atau rekonstruksi system pendidikan Islam di Indonesia, yakni berkiblat kepada (kemajuan) Barat. Seperti diakui seorang

\footnotetext{
${ }^{45}$ Edo Dwi Cahyo, Pendidikan Karakter Guna Menanggulangi, 18.

${ }^{46}$ Kemendiknas, Model Pembinaan Pendidikan Karakter di Lingkungan Sekolah, (Jakarta: Kemendikbud, 2010$), 17$.

47 Haidir, Media Gusman, Nona Kumala Sari, "Implementasi Program Penguatan Pendidikan Karakter (PPK) dalam Pembelajaran Pendidikan Agama Islam," INTIQAD: Jurnal Agama dan Pendidikan Islam, Vol. 12, No. 1 (Juni 2020): 48.

${ }^{48}$ Abdah Munfaridatus Sholihah dan Windy Zakiya Maulida, "Pendidikan Islam sebagai Fondasi Pendidikan Karakter," Kalamuna: Jurnal Pendidikan, Sosial, dan Agama, Vol. 12, No. 1 (2020): 54.

49 Robiatul Awwaliyah, "Pendidikan Islam dalam Sistem Pendiidkan Nasional (Telaah Epistimologi terhadap Problematika Pendidikan Islam)," Jurnal IImiah DIDAKTIKA: Media Ilmiah Pendidikan dan Pengajaran, Vol 19, No. 1 (Agustus 2018): 45.
} 
orientalis Belanda, Karel A. Steenbrink, termasuk system pendidikan Islam di berbagai pesantren di Indonesia telah menerapkan system pendidikan modern yang diadopsi dari model Belanda. ${ }^{50}$

Secara total, system maupun nilai-nilai dalam tradisi pendidikan sufisme seperti ditanamkan dalam tradisi sufisme di Majelis Shalawat Adlimiyah Gus Mursyidin dari para gurunya memang sulit diterapkan dalam praktek pendidikan Islam modern. Tetapi, essensi maupun pokok-pokok ajaran yang menjadi fondasi dasar dapat menjadi spirit atau ruh sistem pendidikan Islam modern. Elemen dasar (ushul atau ushuli) yang menjadi ruh pendidikan Islam dimaksud adalah dimensi nilai maupun ajaran sufisme seperti diskripsi panjang sebelumnya.Beberapa elemen dasar dalam tradisi pendidikan sufisme dari masa ke masa sebagaimana dipraktekkan dan dikembangkan dalam tradisi Majelis Shalawat Adlimiyah Gus Mursyidin maupun gurunya dalam Majelis Shalawat Muhammad serta Shalawat Kubro adalah sebagai berikut;

Pertama, eksistensi guru (mursyid). Selain aspek skill, dimensi inheren dalam diri guru dalam perspektif sufisme adalah dimensi spiritualitas dan karakter (kepribadian atau akhlaq). Seorang guru sufi secara obsolut pasti memiliki karakter mandiri dan independen. Karakter mandiri dan indenpenden menjadi modal dan asset utama dalam membentuk karakter para murid. Karakter dalam arti akhlaq atau kepribadian menjadi garansi bagi guru sufi. Tanpa memiliki akhlaq tidak mungkin membentuk, bahkan melahirkan akhkaq yang sama terhadap para murid. Dalam perspektif sufisme, akhlaq guru yang sempurna equivalen dengan kesempurnaan spiritualitas. Gus Mursyidin dalam berbagai forum Majelis Shalawat Adlimiyah berulang kali menegaskan, dirinya dapat mengetahui dan membaca seluruh dimensi batin dalam diri setiap murid. "Aku ngerti siji-siji neng njero ati mu kabeh," tegasnya. ${ }^{51}$ Sama dengan Gus Mursyidin, Gus Kahar dalam berbagai forum Majelis Shalawat Muhammad sering mengatakan; "Koen singitan neng bumi sap pitu, aku loh ngerti. Ojok coba-coba menyembunyikan sesuatu soko aku." ${ }^{52}$

Kedua, tanggungjawab totalitas guru terhadap murid. Tradisi pendidikan sufisme, seperti dalam Majelis Shalawat Adlimiyah, dinyatakan sendiri Gus Mursyidin. Menurutnya, guru memiliki tanggungjawab penuh terhadap para muridnya. Tanggungjawab ini diemban selama murid memiliki hubungan dengan gurunya dan selama murid masih meyakini sosok gurunya. Dalam hal ini, Gus Kahar pernah menyatakan; "Ora enak dadi wong koyok aku. Di saat kamu tertidur pulas, aku gak turu. Ora onok wong weruh, setiap malam aku keliling ndelok awak mu siji-siji," ungkap Gus Kahar. ${ }^{53}$ Hal yang

\footnotetext{
${ }^{50}$ Miftachul Choiri dan Aries Fitriani, "Problematika Pendidikan Islam sebagai Sub-sistem Pendidikan Nasional di Era Global," Jurnal al-Tahrir Vol. 11, No. 2 (November 2011): 304.

${ }^{51}$ Dinukil dalam Forum Pengajian Majelis Shalawat Adlimiyah Gus Mursyidin, di Pandaan, Pasuruan, 16 Oktober 2019.

52 Dikutip dari Forum Pengajian Majelis Shalawat Muhammad Gus Kahar, di Puri Indah Blok AG, Nomor 12, Sidoarjo, Juni 2015.

${ }^{53}$ Dikutip dari Forum Pengajian Majelis Shalawat Muhammad Gus Kahar, di Puri Indah Blok AG, Nomor 12, Sidoarjo, Juni 2015.
} 
sama juga diungkap Gus Mursyidin; "Aku iki ngerti, sopo wae sing kirim alfatikah neng aku. Fatekah mu yang seng ikhlas iku isok nembus atiku," kata Gus Mursyidin. ${ }^{54}$

Totalitas tanggungjawab guru terhadap murid bukan dimaksud seperti konsep long life education. Dimensi long life education lebih menekankan pada makna kewajiban setiap individu manusia (murid) dalam proses belajar yang tidak pernah berhenti. Sebaliknya, totalitas tanggungjawab dimaksud ada pada setiap guru terhadap para murid. Dalam implementasinya, relasi guru-murid tidak terbatas hanya berhenti dan dibatasi dalam ruang kelas dan jam mengajar seperti fenomena pendidikan Islam modern saat ini. Lebih dari itu, relasi guru-murid juga terus berlangsung di luar dinding ruang kelas dan jam mengajar. Wujud dari tanggungjawab tersebut dapat dibagi ke dalam dua jenis; Pertama, tanggungjawab moral dan spiritual, yakni mendoakan dan support moral terhadap setiap murid. Kedua, mengevaluasi, monitoring, serta mengarahkan masing-masing individu murid.

Tanggungjawab guru terhadap murid setidaknya masih banyak dijumpai dalam tradisi pendidikan pesantren di Indonesia. Meskipun tidak semua pesantren memahami prinsip dasar ini, sebagai generasi ketiga dan keempat dari para kyai pendiri pesantren di berbagai daerah di Indonesia, para kyai generasi penerus orang tuanya masih memegang teguh prinsip-prinsip dasar dalam menyadari tanggungjawab total para santri yang dibebankan dipundaknya. Tanggungjawab total seorang kyai terhadap para santri masih menjadi ciri khas dominan dalam tradisi pendidikan pesantren di Indonesia. ${ }^{55}$ Khazanah praktek pendidikan ala pesantren dalam prakteknya tidak hanya melulu berlangsung dalam dimensi tatap muka selama jam pelajaran. Proses aktivitas belajar berlangsung dalam siklus 24 jam tanpa berhenti.

Ketiga, pembentukan prinsip-prinsip kemandirian. Prinsip kemandirian ini ditekankan oleh Gus Mursyidin dalam mendidik para muridnya, lebih-lebih para murid yang ada dalam lingkaran inti. Menurutnya, seluruh guru sufi selama menjalani fase riyadlah dan salik ditempa melalui kerja keras. Kerja keras ini wujud dan realisasinya berbeda-beda. Kerja keras dapat berupa membantu pekerjaan para gurunya atau kerja keras dalam bentuk mencari rezeki untuk keperluan gurunya. Pengalaman ini dijalani, baik Gus Mursyidin maupun Gus Kahar selama menjadi murid Gus Syamsu Dhuha. Jerih payah kerja keras dalam mengais rezeki bukan untuk dirinya tetapi dipersembahkan bagi gurunya. "Aku biyen arep kuliah, tapi duitku diminta semua oleh Gus Syamsu," kenang Gus Kahar yang juga sebagai guru Gus Mursyidin mengenang perjalanan berguru kepada Gus Syamsu. ${ }^{56}$ Pengalaman berguru yang demikian ini dipraktekkan kepada para murid masing-masing.

\footnotetext{
${ }^{54}$ Dinukil dalam Forum Pengajian Majelis Shalawat Adlimiyah Gus Mursyidin, di Pandaan, Pasuruan, 16 Oktober 2019.

${ }^{55}$ Gatot Krisdiyanto, Muflikha, Elly Elvina Sahara, Choirul Mahfud, "Sistem Pendidikan Pesantren dan Tantangan Modernitas," Jurnal Tarbiyah: Jurnal Ilmu Pendidikan, Vol. 15, No. 1 (Juli 2019).

${ }^{56}$ Dikutip dalam forum Pengajian Majelis Shalawat Muhammad Gus Kahar di Rumah Abah Sukri, Sentul Tanggul Angin, Sidoarjo, Juli 2015.
} 
Di antara lembaga-lembaga pendidikan di Indonesia, lembaga pendidikan Islam berbasis pesantren terbukti secara nyata bukan hanya melulu mengajarkan berbagai teori. Di luar berjibaku dengan teori-teori berupa kitab kuning maupun materi lainnya, para santri diajari para kyai untuk melakukan praktek dalam banyak hal. Sikap kemandirian dalam terminologi modern adalah bagian dari pendidikan karakter. Sistem pendidikan pesantren sejak lama dikenal sebagai system pendidikan yang terbukti melahirkan karakter santri atau murid yang mandiri. ${ }^{57}$ Karakter kemandirian ini dibentuk para kyai melalui spirit Islam yang umumnya diadopsi dari tradisi pendidikan guru-guru sufi masa lalu.

Keempat, output akhir dari prinsip-prinsip dasar sebelumnya adalah membentuk akhlaq, kepribadian, maupun karakter yang kuat para murid. Tujuan dari pendidikan Islam tidak ada bedanya dengan misi Islam yang diemban Nabi Muhammad, yakni rahmat bagi seluruh alam. ${ }^{58}$ Wujud rahmat bagi seluruh alam disimbolisasikan dengan akhlaq, kepribadian, maupun karakter yang kuat. Penegasan ini ada dalam salah satu hadist Nabi yang menjelaskan misi utama Nabi Muhammad diutus untuk menyempurnakan akhlaq manusia. ${ }^{59}$ Karena itu, sesungguhnya antara tujuan pendidikan Islam dengan misi Islam itu sendiri tidak ada bedanya. Dengan demikian, ciri utama dalam diri Nabi Muhammad adalah akhlaq al-Karimah. Dapat dinyatakan, essensi dari keseluruhan ajaran Islam maupun pendidikan Islam itu sendiri dapat disimpulkan dalam dua kata, yakni akhlaq al-Karimah. Essensi ini pula menjadi ciri pembeda yang ditemukan dalam diri para ulama sebagai penerus Nabi Muhammad. Ciri pembeda ini nampak dalam diri para ulama, lebih-lebih ulama sufi (guru atau mursyid) dan para muridnya dengan masyarakat pada umumnya terletak pada kualitas akhlaq alKarimah ini.

Dalam konsepsi umum, output pendidikan sufi di atas dapat menjelaskan tentang hakekat pendidikan karakter. Karakter dalam definisinya dimaknai sebagai jati diri individu yang terbentuk dari akumulasi sikap, pola pikir, dan nilai etis yang diperolehnya dari berbagai interaksi sebagai landasan dalam cara pandang (world view), berfikir, dan bertindak. ${ }^{60}$ Pola pendekatan dalam pendidikan karakter dilakukan melalui 2 (dua) metode; (1) Metode langsung dan (2) Metode tidak langsung. Metode langsung, yakni penentuan perilaku baik sebagai upaya indoktrinasi ajaran. Metode tidak langsung yakni penciptaan situasi yang memungkinkan perilaku baik dapat dipraktekkan. ${ }^{61}$

Pengarusutamaan sufisme ke dalam pendidikan Islam menjadi salah satu solusi dalam menjawab beberapa problem mendasar yang dihadapi lembaga pendidikan Islam kontemporer di

57 Riza Zahriyal Falah, "Membangun Karakter Kemandirian Wira Usaha Santri melalui Sistem Pendidikan Pondok Pesantren," Jurnal Tarbawi, Vol. 15, No. 2 (Juli-Desember 2018): 116.

58 Liat, al-Qur'an: SQ: 107, yakni: “Wa ma arsalna ka illa rahmat li al-'Alamin," (Dan Aku tidak mengutus Engkau (Muhammad) melainkan untuk (menjadi) rahmat bagi seluruh alam).

${ }^{59}$ Hadist dari Abu Hurairah: "Sesungguhnya aku diutus untuk menyempurnakan akhlaq," lihat: Al-Bukhari, Adab alMufrad, hadist No. 273.

${ }^{60}$ Siti Zazak Soraya, "Penguatan Pendidikan Karakter untuk Membangun Peradan Bangsa," Southeast Asian Journal of Islamic Education Management, Vol. 1 (1), (2020): 76.

${ }^{61}$ Siti Zazak Soraya, "Penguatan Pendidikan Karakter": 79. 
Indonesia. Dekadensi moral yang menjadi keprihatinan masyarakat diyakini dapat diminimalisir melalui pendekatan sufisme. Selain itu, pendidikan karakter sebagai jawaban atas dekadensi moral tersebut sesungguhnya telah lama menjadi model dan ideal type dalam tradisi pendidikan sufi. Nilai-nilai sufisme ini sesuai dengan paradigma pendidikan Islam modern dengan 3 (tiga) paradigma, yakni (1) Paradigma holistik, (2) Paradigma humanistik, dan (3) Paradigma pluralistik. ${ }^{62}$ Ketiga paradigma tersebut ruhnya adalah dimensi spiritualitas, yakni internalisasi nilai-nilai ketuhanan dalam setiap individu murid. Di sinilah nilai-nilai maupun perspektif sufisme mendapat momentum dalam menjawab dilema dan problematika pendidikan Islam kontemporer.

\section{Kesimpulan}

Berdasarkan analisis terhadap psudo-sufi, Majelis Shalawat Adlimiyah di atas, nampak jelas sekali peran fundamental, krusial, dan signifikan akan nilai-nilai sufisme dalam system pendidikan Islam. Artinya, nilai-nilai sufisme dapat diterapkan dalam konteks dan ranah pendidikan Islam secara umum dan dalam dimensi Indonesia kontemporer saat ini. Analisis yang didasarkan atas riset partisipatoris pada Majelis Shalawat Adlimiyah di Bojonegoro dan Pandaan menerapkan standar tinggi (high standart) ajaran sufisme terhadap para muridnya dalam kehidupan praksis sehari-harinya. Standar tinggi ini berupa tradisi riyadlah, salik, serta mujahadah secara ketat yang secara turun temurun diwarisinya dari para gurunya serta berlaku dalam sistem pendidikan sufisme klasik. Sistem pendidikan ini membentuk relasi guru-murid sekaligus mewarisi(kan) intellectual chains. Eksistensi peran guru dalam konteks tradisi pendidikan sufi menempati posisi sentral.

Dalam epistimologi pendidikan Islam, eksistensi guru secara metafora merepresentasikan sebagai Nabi maupun Tuhan. Dalam diri guru, sifat-sifat kenabian dan ketuhanan ada dalam dirinya. Karena itu, system ini menjamin terjadinya transfer of knowledge dari guru kepada murid. Selain itu, sifat kenabian dan ketuhanan dalam diri guru ini berimplikasi dalam membentuk akhlaq al-Karimah dalam pribadi murid sebagaimana kepribadian gurunya. Sistem dan tradisi pendidikan Islam dalam khazanah pendidikan Islam klasik terbukti mampu mereproduksi para sarjana muslim secara baik. Oleh karena itu, dalam konteks pendidikan Islam Indonesia kontemporer, nilai-nilai sufisme sebagai fundasi dasar system pendidikan Islam menjadi kebutuhan mendesak untuk diimplementasikan secara sungguh-sungguh.

Akhlaq sebagai kata kunci dari tujuan pendidikan Islam tidak lain diduplikasi atau disublimasi dari ajaran atau doktrin sufisme. Akhlaq atau akhlaq al-Karimah sebagai output pendidikan Islam secara essensi merupakan pendidikan karakter yang menjadi diskursus ramai di kalangan para akademisi akhir-akhir ini. Pendidikan karakter yang menjadi diskursus ini secara nyata telah menjadi

\footnotetext{
62 Hikma H. Amidong, Nursyamsi Maulana Insani, dan Andreawan, "Paradigma Pendidikan Islam masa kini dan masa depan," Jurnal Didaktika: Media Ilmiah Pendidikan dan Pengajaran, INA-Rxiv Papers (Januari 2019): 6-11.
} 
ideal type dan model di berbagai institusi sufi. Dengan kata lain, akhlak dalam pendidikan Islam dimaksud secara spesifik lebih merujuk kepada doktrin maupun ajaran sufisme. Dekadensi moral maupun berbagai derivasi problematika pendidikan yang dihadapi dan dikeluhkan oleh para praktisi pendidikan saat ini terbukti bukan menjadi persoalan bagi institusi pendidikan Islam yang menempatkan sufisme sebagai ruh pendidikan.

\section{E. Referensi}

Akbar, Ali. "Looking at Ibn 'Arabi's Notion of Wihdat al-Wujud as Basis for Plural Path to God." Journal of Islamic Studies and Culture, 2016: 45-51.

Akmaliah, Wahyudi. "Kebenaran yang Terbelah: Populisme Islam dan Disinformasi Politik Elektoral." Ma'arif, 2019: 139.

Alba, Cece. Cahaya Tasawuf. Bandung: CV. Wahana Karya Grafika, 2009.

al-Ghazali, Imam. Ayyuha al-Walad. al-Haramain Jaya, tt.

-. Ihya Ulum al-Din, Bab al-Halabi. Cairo: tanpa penerbit, $1343 \mathrm{H}$.

al-Jarnuzi, Burhan al-Islam. Ta'lim al-Muta'allim Tariq al-Ta'lim. Dar Ihya' al-Kutub al-`Arabiyah, t.th.

al-Jilli, Abdul Karim ibnu Ibrahim. al-Insan al-Kamil fi Makrifat al-Awakhiri wa al-Awaili. Lebanon: Dar al-Khutub al-IImiyah, 2010.

al-Quran.

Asy'ary, KH. Hasyim. Adab al-Alim wa al-Muta'allim. Jombang: PP. Tebu Ireng, tanpa tahun.

Awwaliyah, Robiatul. "Pendidikan Islam dalam Sistem Pendiidkan Nasional (Telaah Epistimologi terhadap Problematika Pendidikan Islam)." Jurnal IImiah DIDAKTIKA: Media IImiah Pendidikan dan Pengajaran, 2018: 45.

Bahri, Media Zainul. "Ibn 'Arabi and the Transendental Unity of Religions." Al-Jamiah, 2012: 461-481.

Cahyo, Edo Dwi. "Pendidikan Karakter Guna Menanggulangi Dekadensi Moral yang Terjadi pada Siswa Sekolah Dasar." Eduhumaniora: Jurnal Pendidikan Dasar, 2017: 16.

Falah, Riza Zahriyal. "Membangun Karakter Kemandirian Wira Usaha Santri melalui Sistem Pendidikan Pondok Pesantren." Jurnal Tarbawi, 2018: 116.

Fanani, Ahmad Fuad. "Fenomena Radikalisme di Kalangan Anak Muda." Ma'arif, 2013: 4-13.

Faturohhman, Oman. "Kontribusi Pendidikan Karakter dalam Sistem Pendidikan Nasional." Eduprof, $2019: 1$.

Feener, Micheal. A Re-Examanation of the Place of al-Hallaj in the Development of Southeast Asian Islam. Leiden : KITLV, 1998.

Fitriani, Miftachul Choiri dan Aries. "Problematika Pendidikan Islam sebagai Sub-sistem Pendidikan Nasional di Era Global." Jurnal al-Tahrir, 2011: 304.

Gatot Krisdiyanto, Muflikha, Elly Elvina Sahara, Choirul Mahfud. "Sistem Pendidikan Pesantren dan Tantangan Modernitas." Jurnal Tarbiyah: Jurnal IImu Pendidikan, 2019.

Haidir, Media Gusman, Nona Kumala Sari. "Implementasi Program Penguatan Pendidikan Karakter (PPK) dalam Pembelajaran Pendidikan Agama Islam." INTIQAD: Jurnal Agama dan Pendidikan Islam, $2020: 48$. 
Hikma H. Amidong, Nursyamsi Maulana Insani, dan Andreawan. "Paradigma Pendidikan Islam masa kini dan masa depan." INA-Rxiv Papers. Jurnal Didaktika: Media Ilmiah Pendidikan dan Pengajaran, 2019. 6-11.

Huda, Muhammad Nurul. Intoleransi Kaum Muda di Tengah Kebangkitan Kelas Menengah Muslim Perkotaan. Jakarta: Wahid Institute, 2017.

Iskarin, Mochammad. " Dekadensi Moral di Kalangan Pelajar: Revitalisasi Strategi PAl dalam Menumbuhkan Moralitas Generasi Bangsa." Edukasi Islamika, 2016: 1-15.

Kahar, Gus, interview by Rubaidi. bincang santai (Juni 14, 2015).

Kemendiknas. Model Pembinaan Pendidikan Karakter di Lingkungan Sekolah. Jakarta: Kemendikbud, 2010.

Maulida, Abdah Munfaridatus Sholihah dan Windy Zakiya. "Pendidikan Islam sebagai Fondasi Pendidikan Karakter." Kalamuna: Jurnal Pendidikan, Sosial, dan Agama, 2020: 54.

Mukarramah, Oom. "Ittihad, Hulul, dan Wahdat al-Wujud." Jurnal Tazkiya, 2015: 129-141.

Mursyidin, Gus, interview by Rubaidi. Mursyid Sholawat Adlimiyah (Juli 16, 2019).

"Nomor 14 tentang Guru dan Dosen, bab IV, tentang kualifikasi, kompetensi, dan sertifikasi." Undangundang Republik Indonesia, 2005.

"Nomor. 55, tentang Pendidikan Agama Islam dan Keagamaan, terutama Bab I, Ayat 1." Peraturan Pemerintah, 2007.

Nudin, Burhan. "Konsep Pendidikan pada Remaja." LIERASI, 2020: 63-73.

Penyusun, Tim. Grand Design Pendidikan Karakter Bangsa. Jakarta: Kementerian Pendidikan Nasional , 2011.

Pratama, A.R.Iga Megananda. "Urgensi dan Signifikansi Mursyid bagi Murid dalam Tarekat." Jurnal Yaqzhan, 2018: 54-55.

Rahmawan, Abdur Rahman dan Alvin Dwi. "Memperkuat Modal Sosial di Kalangan Umat Islam di Era Post-Truth." Supremasi: Jurnal Pemikiran dan IImu-ilmu Sosial, Hukum dan Pengajaranya, 2019: 172.

Soraya, Siti Zazak. "Penguatan Pendidikan Karakter untuk Membangun Peradan Bangsa." Southeast Asian Journal of Islamic Education Management, 2020: 76.

Sunarso, Ali. "Revitalisasi Pendidikan Karakter melalui Internalisasi Pendidikan Agama Islam (PAI) dan Budaya Religius." Kreatif: Jurnal Kependidikan Dasar, 2020: 158.

Sunyoto, Agus. Atlas Wali Songo: Mengungkap Wali Songo sebagai Fakta Sejarah. Jakarta: Pustaka Iman, 2017.

Ulya. "Post Truth, Hoax, dan Religiusitas di Media Sosial." Fikrah: Jurnal Ilmu Aqidah dan Studi Keagamaan, 2018: 283-299.

Untung, interview by Rubaidi. salah seorang kakak Gus Mursyidin dan murid dari Gus Syamsu Dhuha dan Gus Kahar (Agustus 19, 2019).

Wahyudi, Tian. "Strategi Pendidikan Akhlaq bagi Generasi Muda di Era Disrupsi." TA'LIM: Jurnal Studi Pendidikan Islam, 2020: 15. 